\title{
GERIATRIC DEPRESSION AND COPING STRATEGIES OF PENALIZED OLDER ADULTS
}

\author{
Janet Alexis A. De Los Santos ${ }^{1 *}$, Arleth Faith Loreno², Maria Reza Talaboc ${ }^{2}$ \\ ${ }^{1}$ Department of Nursing, Visayas State University, Leyte, Philippines \\ ${ }^{2}$ Visayas State University, Baybay City, Leyte, Philippines \\ *Corresponding Author’s Email:janetalexis.delossantos@vsu.edu.ph
}

\begin{abstract}
The older adult prisoners are the most vulnerable to the pressures and the harsh conditions in the prison environment which may be deteriorating and compromising both to their physical and mental health conditions. We have turned our attention towards this research to learn about both physical and psychological status of the older adult prisoners. Using a descriptive design, we gathered data through faceto-face interview using the questionnaires: Geriatric Depression Scale Short Form and Coping Strategies Inventory. The researchers also assessed the physical condition through review of systems. Results revealed that there are physical issues experienced by the older prisoners which are common in old age. There is mild to severe depression among $80 \%$ of the participants. Despite the remarkable physical and mental situations, they are in, there are several positive coping strategies used by the older prisoners in dealing with their everyday challenges inside prison. Nursing as a profession are non-selective and non-discriminatory in caring even to these neglected yet vulnerable group. The results of the study may be utilized in understanding the current situation of this sector to provide appropriate interventions and strategies catering to their needs in health and well-being.
\end{abstract}

\section{Keywords: Older Adult, Prisoners, Geriatrics, Depression, Coping}

\section{INTRODUCTION}

Older prisoners are increasing in different countries worldwide such as the UK, USA and Australia. The same is true with the current situation in the Philippines (Aday \& Krabill, 2012; Baidawi et al., 2011). Everyone who enters prison is subjected to many pressures of institutionalization. Prisons are usually designed for younger offenders and not considering the possible needs of the elder group. This may include greater distances between facilities and the lack of supportive equipment among others. Prisoners respond in different ways with varying degrees of psychological change associated with their adaptations. The older adult prisoners are the least dangerous group of people behind bars but the most expensive to incarcerate. Many elderly prisoners committed a crime in their younger years where they received longer custodial sentences as the courts' verdict. Some are in prison for nonviolent offenses, while some are in prison at an older age. Most of the prisoners belong to a low socioeconomic status, so that they are incapable of financing the lawyer to defend themselves in the court that often lead to failure of their case. The older adult prisoners are the most vulnerable to these pressures and are unable to cope with the overall pains of imprisonment than the younger age groups. Haney (2001) suggested that the psyche of an inmate is challenged and is dependent upon the existing environment. The prison policies, harsh confinement conditions such as those in solitary confinement predisposes physical and psychological problems leading to difficulties in the transition from prison to home (Haney, 2001; Wolff, 2005). The harsh conditions may even be deteriorating for the older age group. Most often than not, older adult prisoners are the most neglected and marginalized sectors in a prison environment (Crawley, 2005). 
We have turned our attention towards this research to know both physical and psychological status of the older adult prisoners. By determining the health conditions, mental status and coping strategies, their institutionalized living conditions will be contextualized which may be utilized as an input for policy development and interventions to meet the needs of this sector.

\section{METHODOLOGY}

\section{Research Design}

The researchers in this study utilized a descriptivecorrelational design by observing, document. The study detected the relationships among variables, without seeking to establish causal connections. It is in the interest to determine the presence of geriatric depression and Coping Strategies of these prisoners for significant relationships.

\section{Research Respondents}

To meet the needs of this research, pre-selection was done. Like other studies conducted (Kakoullis, Mesurier \& Kingston, 2010), the disproportion of sex distribution among the imprisoned prompted the researchers to prefer the male older adults. Male prisoners aged 60 and above were the only ones scheduled for an interview. A total of 60 males aged 60 and above participated and provided the needed data. No sampling was done, but instead, the researchers decided to take all respondents who qualified in the selection criteria.

\section{Locale of the Study}

A local prison in the Philippines was selected for this study considering that it provides the most significant number of older adult prisoners in the country. The characteristics of convicted inmates in this prison hold a variety of causes for incarceration. The most common are those considered on maximum security, classified as heinous and controversial. The institute has a prisoner capacity of 500 and implements correctional programs in addition to rehabilitation activities.

\section{Research Instruments}

To elicit a high response rate, an interview schedule was the preferred method in gathering data. A face-to- face interview using a prepared 4-part questionnaire was used to collect the needed information. Part One is the Review of Systems. This is a physical assessment initiated by the researcher which may be subjectively answered by the respondent. Section two assesses background information of the respondents. This includes basic demographic profile as well as the number of years and length of sentence in prison. Part three is the Geriatric Depression on Scale: Short Form. The instrument is also known as the GDS where it has well-established reliability and validity evaluated against other diagnostic criteria. Responses were considered along with results from a comprehensive diagnostic workup. It is composed of 15 sets of question answerable by Yes or No. Each item scores as either 0 or 1 point. The scale is commonly for use as a routine comprehensive geriatric assessment (Greenberg, 2012). One-point assigns to each answer, and the cumulative score is rated on a scoring grid. The grid sets a range of 0-9 as "normal, " 10-19 as "mildly depressed," and 2030 as "severely depressed." It has demonstrated moderate reliability. Friedman and colleagues reported moderate internal consistency (a Cronbach a coefficient of 0.749). Part four is the Coping Strategy Inventory. It is 72-item self-report questionnaires designed to asses coping thoughts and behaviors in response to stressors. The respondents taking the CSI are asked to respond to 72 questions in a 5-item Likert format. The participants indicated for each item the extent to which they performed that particular coping response in dealing with the previously described situation. Cronbach's alpha ranges from 0.71-0.94 and has been the most frequently reported coefficient of reliability for measures of coping process.

\section{Data Gathering Procedure}

The researchers seek permission from the administration to conduct the study outside university premises. A permit likewise was asked from the designated Superintendent of the local prison. The respondents were made to sign an informed consent. The researchers clarified that their participation in the study is optional and voluntary. A face-to-face interview schedule was the method of choice in the gathering of data to elicit high response rate and to conduct the systems review personally with the respondent. The 
researchers opted this method to facilitate an efficient data collection. Most participants had a hard time reading and understanding the questions perhaps because of their age. Providing assistance to some respondents is essential especially to those who were unable to understand some portions of the questionnaire.

\section{RESULTS AND DISCUSSION}

\section{Review of Systems: Assessing the Inmates Health}

A rundown of physical assessment of the older adults was done to determine their health status. It was found that regarding the general well-being of inmates the common complaint is fatigue, weakness, weight loss and trouble in sleeping. From a total respondent of 60,36 or $60 \%$ complained that fatigue bothers them most. Weakness ranks the second having 32 or $53.3 \%$. There are 17 or $28.3 \%$ who claimed weight loss in the past four years. Ten (10) or $16.7 \%$ of the inmates also claimed that they had trouble sleeping especially at night. For skin complaints, there are 8 or $13.3 \%$ who reported generalized itching and $6.7 \%$ and 4 said that they experienced presence of lumps in their body. There are 17 inmates or $28.3 \%$ who complained about a headache. Moreover, the most common complaint is ringing-like sounds in the ears and decreased hearing which accounted for $41 \%$ and $33 \%$ respectively. A variety of eye complaints were also gathered. The most common complaint of respondents is blurry or double vision $(63.3 \%)$, vision loss/changes $(8.3 \%)$, use of eyeglasses $(8.3 \%)$, pain $(8.3 \%)$, and redness $(6.7 \%)$. There were 11 respondents or $18.3 \%$ who were experiencing rhinitis during the conduct of the assessment. In relation to the respiratory problem, the most common complaints were dry cough for 16 or $26.7 \%$, productive cough for 5 or $8.3 \%$. Two or $3.3 \%$ experienced difficulty in breathing, cough with blood for 1 or $1.7 \%$. Problems of the respiratory system needs immediate attention and further medical evaluation since most often it is suggestive of a communicable infection. Considering the congestion and living condition of the inmates, cross-contamination, and spread of disease is inevitable and therefore requires immediate action for control or isolation. There are several cardiovascular issues including hypertension (35\%), calf pain (11.7\%), leg cramps (10\%), shortness of breath with activity $(6.7 \%)$, chest discomfort/pain
(3.3\%), difficulty of breathing when lying flat (3.3\%), swelling of one or both feet $(3.3 \%)$, and sudden awakening from sleep with shortness of breath (3.3\%). The most common gastrointestinal complaint includes stomach pain (13.3\%), followed by heartburn (5\%) and change in appetite $(5 \%)$. Some respondents aired some concerns related to their urination. This includes pain in the flank area $(8.3 \%)$, pain in urination $(3.3 \%)$, and frequent urination $(3.3 \%)$. There were reported musculoskeletal problems such as muscle or joint pain $(28.3 \%)$ and back pains $(26.7 \%)$. The most reported neurologic issues are numbness of hand or feet $(51.7 \%)$, tingling of hands or feet $(28.3 \%)$, and tremors $(8.3 \%)$. It was noted that the inmates have concerns related to their endocrine system. The most reported problem was heat or cold intolerance $(60 \%)$, cold sweat (11.7\%), unusual thirst (5\%), change in appetite $(3.3 \%)$ and frequent urination $(1.7 \%)$. In terms of the Psychiatric or Psychological problem, they mostly complained about nervousness $(28.3 \%)$, followed by memory loss (20\%), depression (11.7\%), stress (3.3\%), and mood changes $(1.7 \%)$.

Based on the findings of the Review of Systems, the health profile of the prisoners presents common health manifestations among elderly. These findings are reflective of their old age and therefore needs attention to implement cost-efficient measures at the same time providing their health needs. Health as a fundamental human right must be presented without bias to age and criminal records or imprisonment. By doing this social justice is preserved and incurring expensive treatment and rehabilitation is mitigated aside from it being a constitutional obligation and a moral responsibility. A practical, cost-effective strategy on the part of the criminal justice system must be practiced. Such institute must implement preventive health care in this sector (Williams et al., 2012).

Moreover, this drastic change and the deterioration of their physical condition aside from their natural senility are brought about by fear of being labeled as malingerers. Silence and preferring not to communicate their ailments may be a behavior being done by the older groups for fear of rejection and being mistaken as malingering. This is an unsafe and unhealthy behavior compromising health and expensive practice. 
Table 1: Findings on the inmates Review of Systems

\begin{tabular}{|c|c|c|c|}
\hline $\begin{array}{c}\text { Assessment } \\
\text { Area }\end{array}$ & Complaints & $\begin{array}{l}\text { No. of } \\
\text { inmates }\end{array}$ & Percent \\
\hline \multirow{4}{*}{$\begin{array}{l}\text { General well } \\
\text { being }\end{array}$} & Fatigue & 36 & 60.0 \\
\hline & Weakness & 32 & 53.3 \\
\hline & Weight loss & 17 & 28.3 \\
\hline & Trouble sleeping & 10 & 16.7 \\
\hline \multirow[t]{2}{*}{ Skin } & Itching & 8 & 13.3 \\
\hline & Lumps & 4 & 6.7 \\
\hline Head & Headache & 17 & 28.3 \\
\hline \multirow[t]{2}{*}{ Ears } & Ringing-like sounds & 25 & 41.7 \\
\hline & Decreased hearing & 20 & 33.3 \\
\hline \multirow[t]{5}{*}{ Eyes } & Blurry or double vision & 38 & 63.3 \\
\hline & Vision changes & 5 & 8.3 \\
\hline & Use of glasses & 5 & 8.3 \\
\hline & Pain & 5 & 8.3 \\
\hline & Redness & 4 & 6.7 \\
\hline Nose & Discharge & 11 & 18.3 \\
\hline \multirow[t]{4}{*}{ Respiratory } & Dry cough & 16 & 26.7 \\
\hline & Productive cough & 5 & 8.3 \\
\hline & Difficulty in breathing & 2 & 3.3 \\
\hline & Cough with blood & 1 & 1.7 \\
\hline \multirow[t]{7}{*}{ Cardiovascular } & Hypertensive & 21 & 35.0 \\
\hline & Calf pain & 7 & 11.7 \\
\hline & leg cramps & 6 & 10.0 \\
\hline & $\begin{array}{l}\text { Shortness of breath } \\
\text { with activity }\end{array}$ & 4 & 6.7 \\
\hline & Chest discomfort/pain & 2 & 3.3 \\
\hline & $\begin{array}{l}\text { Difficulty of breathing } \\
\text { lying flat }\end{array}$ & 2 & 3.3 \\
\hline & $\begin{array}{l}\text { Swelling of one or } \\
\text { both feet }\end{array}$ & 2 & 3.3 \\
\hline
\end{tabular}

\begin{tabular}{|c|c|c|c|}
\hline \multirow[t]{3}{*}{ Gastrointestinal } & Stomach pain & 8 & 13.3 \\
\hline & Heartburn & 3 & 5.0 \\
\hline & Changes in appetite & 3 & 5.0 \\
\hline \multirow[t]{3}{*}{ Urinary } & Lower back pain & 5 & 8.3 \\
\hline & Pain in urination & 2 & 3.3 \\
\hline & Frequent urination & 2 & 3.3 \\
\hline \multirow[t]{2}{*}{ Musculoskeletal } & Muscle or joint pain & 17 & 28.3 \\
\hline & Back pain & 16 & 26.7 \\
\hline \multirow[t]{3}{*}{ Neurologic } & $\begin{array}{l}\text { Numbness of hands } \\
\text { or feet }\end{array}$ & 31 & 51.7 \\
\hline & Tingling of hands or feet & 17 & 28.3 \\
\hline & Tremors & 5 & 8.3 \\
\hline \multirow[t]{5}{*}{ Endocrine } & Heat or cold intolerance & 24 & 40.0 \\
\hline & cold sweat & 7 & 11.7 \\
\hline & Unusual thirst & 3 & 5.0 \\
\hline & Change in appetite & 2 & 3.3 \\
\hline & Frequent urination & 1 & 1.7 \\
\hline \multirow{5}{*}{$\begin{array}{l}\text { Psychiatric/ } \\
\text { Psychological }\end{array}$} & Nervousness & 17 & 28.3 \\
\hline & Memory loss & 12 & 20.0 \\
\hline & Depression & 7 & 11.7 \\
\hline & Stress & 2 & 3.3 \\
\hline & Mood changes & 1 & 1.7 \\
\hline
\end{tabular}

\section{Socio-Demographic Characteristics of Elderly Male Prisoners}

Out of sixty 60 respondents, 36 or $60.0 \%$ are aged between $60-69,20$ or $33.3 \%$ are $70-79$ years old, 4 or $6.7 \%$ are 80 years old and above. These older adult prisoners were not able to finish elementary level of education ( $n=39,65 \%)$, most are married ( $n-34,56.67 \%)$ and has farming ( 40 or $66.7 \%$ ) as their primary source of living before they got imprisoned. There were 8 or $13.3 \%$ worked as a fisherman, 9 or $15 \%$ worked as minimum wage earners on occasional hard labor jobs. 
Majority of these inmates $(n=25,41.7 \%)$ served their sentences for less than five years followed by those in prison for almost for 5-9 years $(n=21,35 \%)$, where most had a case of Homicide $(n=33,55 \%)$ followed by Murder/frustrated murder ( $\mathrm{n}=17,28.3 \%)$.

The figures speak that these older adult prisoners belong to low socioeconomic status and did not get an excellent educational foundation. School is one of the main contributors to values and academic formation of a child, and the lack of it hinders one to find a decent job in the future to support self and family needs. Due to the lack of opportunities to find a high paying job they resorted to other means of income that did not require competitive educational qualifications such as farming, fishing. The Philippines as a country remains to be a rural economy where farmers' income is generally quite low ('Poverty in the Philippines', 2012). However, some works of literature suggest that the lack of adequate income may predispose an individual to commit crime (Patterson,1991). It can be surmised that because of the lack of education and low socioeconomic status, these older prisoners were predisposed to several factors that caused them to get engage in criminal acts.

Based on these profiles, most of the respondents are newly confined behind bars and serving their sentences for the last five years. Moreover, they will be spending at least ten years or more in prison to serve their sentences. Such that returning to the free community will be after reaching the age of 70-80 years old. Studies are suggesting that some 60-year-old can experience adverse of geriatric problems in the prison, making these group vulnerable to the physical changes and the odds of old age (Williams et al., 2006). The National Institute of Corrections in the US even consider the age of 50 as old needing the same considerations as those aging 60 or more (Anno et al., 2004). Physical health may be compromised more evidently soon after incarceration and may come in forms of cardiovascular, musculoskeletal, digestive and respiratory problems (Kakoullis, Le Mesurier \& Kingston, 2010). Although it is understandable that as prisoners they are to serve their penitentiary obligations, there is a need to look after the welfare of the older group as they are the susceptible towards real issues on health.
Table 2: Demographic Profile of the Older Adult Prisoners

\begin{tabular}{|c|c|c|c|}
\hline Variable & Category & $\begin{array}{l}\text { No. of } \\
\text { inmates }\end{array}$ & Percent \\
\hline \multirow[t]{3}{*}{ Age } & 60 to 69 & 36 & 60.0 \\
\hline & 70 to 79 & 20 & 33.3 \\
\hline & 80 and above & 4 & 6.7 \\
\hline \multirow{6}{*}{$\begin{array}{l}\text { Highest grade } \\
\text { completed }\end{array}$} & Never been in school & 4 & 6.7 \\
\hline & Elementary level & 39 & 65.0 \\
\hline & Elementary graduate & 11 & 18.3 \\
\hline & High school level & 2 & 3.3 \\
\hline & High school graduate & 3 & 5.0 \\
\hline & College level & 1 & 1.7 \\
\hline \multirow[t]{3}{*}{ Marital status } & $\begin{array}{l}\text { Single/Separated/ } \\
\text { Deceased spouse }\end{array}$ & 17 & 28.33 \\
\hline & Married & 34 & 56.67 \\
\hline & $\begin{array}{l}\text { Living with a partner but } \\
\text { not married }\end{array}$ & 9 & 15.0 \\
\hline \multirow[t]{4}{*}{ Occupation } & $\begin{array}{l}\text { Occasional Laborer } \\
\text { (minimum wage) }\end{array}$ & 9 & 15 \\
\hline & Driver & 3 & 5.0 \\
\hline & Farmer & 40 & 66.7 \\
\hline & Fisherman & 8 & 13.3 \\
\hline \multirow[t]{4}{*}{ Years in prison } & $<5$ years & 25 & 41.7 \\
\hline & 5 to 9 years & 21 & 35.0 \\
\hline & 10 to 14 years & 6 & 10.0 \\
\hline & 15 years or more & 8 & 13.3 \\
\hline \multirow{3}{*}{$\begin{array}{l}\text { Minimum } \\
\text { sentence }\end{array}$} & $<5$ years & 13 & 21.7 \\
\hline & 5 to 9 years & 31 & 51.7 \\
\hline & 10 to 14 years & 16 & 26.7 \\
\hline \multirow[t]{5}{*}{ Maximum sentence } & $<5$ years & 1 & 1.7 \\
\hline & 5 to 9 years & 6 & 10.0 \\
\hline & 10 to 14 years & 37 & 61.7 \\
\hline & 15 years or more & 14 & 23.3 \\
\hline & Lifetime & 2 & 3.3 \\
\hline \multirow[t]{5}{*}{ Cases } & Rape/Attempted rape & 4 & 6.7 \\
\hline & $\begin{array}{l}\text { Murder/Frustrated } \\
\text { murder }\end{array}$ & 17 & 28.3 \\
\hline & Homicide & 33 & 55.0 \\
\hline & $\begin{array}{l}\text { Theft/Qualified } \\
\text { theft/Robbery }\end{array}$ & 3 & 5.0 \\
\hline & $\begin{array}{l}\text { Staffa/Malversation of } \\
\text { public funds }\end{array}$ & 3 & 5.0 \\
\hline
\end{tabular}




\section{Depression of the Older Adult Inmates}

Out of 60 respondents, 12 or $20.0 \%$ inmates normally scored in the geriatric depression scale. Remarkably, forty-four or $73.3 \%$ showed a mild/ suggestive depression while 4 or $6.7 \%$ had severe depression. The depression accounts for $80 \%$ of elderly prisoners who are psychologically disturbed. This result is similar to the study of Murdoch et al., (2008) who also used the Geriatric Depression Scale and established that the majority of the prisoner respondents also have mild depression. They linked the increasing age, chronic illness, psychiatric history and low scores on MMSE from the other factors' contributory to feelings of depression.

Depression is found to be the most common manifestation among older adult prisoners. Most of the inmates have mild/suggestive depression because they have dropped many of their activities since imprisonment. The findings of this study are similar to Aday \& Krabill (2012) who reported that more than half of all older adults who are incarcerated experience psychological distress, unfortunately, this may even lead to mental illness. The major life event such as imprisonment requires adjustment needed all throughout the days of their lives. The everyday routine became highly structured and limited according to the correctional program of the institution. These pose a threat to his sense of achievement and self-actualization now that his psychological need for integrity is in question. Crawley \& Sparks (2005) suggested, this may be a result of the loss of certain aspects of his identity and is stigmatized through negative labels causing them to have a 'spoiled identity.' Fear of rejection and discrimination is one of the troubling concerns of this sector. The fact of being incarcerated and deprived of freedom is a taint to their personal identity. Their friends or even families may show indifference and detachment compromising their need for belongingness, love, and acceptance.

\section{Table 3: Geriatric Depression Scores of the Older} Adult Prisoners

\begin{tabular}{|l|c|c|}
\hline Category & Frequency & Percent \\
\hline Normal & 12 & 20 \\
\hline Mild/Suggestive Depression & 44 & 73.3 \\
\hline Severe Depression & 4 & 6.7 \\
\hline Total & 60 & 100 \\
\hline
\end{tabular}

\section{Coping strategies of Older Adult Prisoners}

There are several positive coping strategies utilized by the older adult prisoners. There are thirty-nine or $65 \%$ who considers social support as an effective coping strategy. The same number of inmates wished that their situation would change and hope for a miracle to happen, as their adaptive strategy to cope. Thirty-three (55\%) inmates feel that by expressing their emotions by letting it out is useful in their coping. Cognitive restructuring is another method of coping being utilized by 32 or $53.3 \%$ inmates. They convince themselves that things are not entirely perilous as they seem. They reorganized the way they look at the situation and it was not so devastating. Avoidance as a means of coping strategy practiced by 31 or $51.7 \%$ of inmates. They continue living their lives as if nothing happened; they $\mathrm{r}$ avoid thinking about their current situation or does not do anything regarding the present situation as an escape. Some inmates (26 or $43.3 \%$ ) recognize problem-solving as an effective means. They worked on solving problems based on the situation. They make plans of action and implement it thereafter.

There were 21 or $35 \%$ out of 60 respondents who experience self-criticism. They criticized themselves for what happened, and they blame themselves for everything that has happened. Some of these respondents are still not able to cope with their present situation. There were 8 or $13.3 \%$ of inmates who experience social withdrawal and preferred to spend time alone and avoided being with people.

Moos (1974) have suggested that coping is indicatory of personal characteristics. It is also a process that is dependent on the situation where a person is in (Lazarus \& Lazarus, 2006) as postulated in the Self-efficacy theory by the renowned author Bandura (1977). In other words, the process of coping mirrors a person's inherent flexibility and adaptability. People being dynamic systems can adapt to change which is also the same among adult prisoners. The ability to create positive interactions with his new environment is the most common adaptive coping strategies of the older adult prisoner in this study. In spite of the odds of his situation, the respondents can face the situation with courage and certainty. Adaptations are necessary to prepare them to cope with changes in himself as a person is always vulnerable to the changes in his environment. Alternatives are set 
forth as a means to compensate for the loss to create a balanced. The person must be able to choose from the available alternatives. It is through this process one can overcome successfully a critical and stressful life event. Adaptation creates a positive development and enhances life satisfaction. Generally, the results of this study support other researches suggesting that the more adaptive a prisoner is to his current position, the better will be his quality of life (Bjorklof et al., 2013). Several interventions are focusing on addressing the issues of geriatric care among the older group. There is one study conducted focusing on providing recreational interventions like provision of traditional Filipino art works, that has potential therapeutic effects among the older adult (De Guzman et al., 2010). The technique may be applied to these group to improve their sense of well-being and outlook towards life.

Table 4: Coping Strategies of the Older Adult Prisoners

\begin{tabular}{|l|c|c|}
\hline Coping Strategy & Frequency & Percent \\
\hline Social Support & 39 & 65 \\
\hline Wishful Thinking & 39 & 65 \\
\hline Express emotions & 33 & 55 \\
\hline Cognitive Structuring & 32 & 53.3 \\
\hline Problem Avoidance & 31 & 51.7 \\
\hline Problem Solving & 26 & 43.3 \\
\hline Self -Criticism & 21 & 35 \\
\hline Social withdrawal & 8 & 13.3 \\
\hline
\end{tabular}

\section{CONCLUSION}

The results of this study present the real situation of older prisoners in a penal institution. Undeniably, there are physical ailments and health issues experienced by the older inmates considering the changes in old age. But along with this mental health is another area that must be taken into consideration. The older prisoners are mentally distressed which may be cause significant changes in the life event of the prisoner. Coping strategies help them in the adjustment and sustaining a positive outlook towards life throughout this period despite their challenging situation.

The results of this study provide an additional learning for nurses on how to care for geriatric cases, specifically for the penalized. Nurses as a profession provides care. Caring in nursing is unbiased and nondiscriminatory of patient's conditions and situations. Anchored on Parse Theory of Human Becoming (1997), holistic nursing must always be practiced where a nurse must not only focus on the physical needs but likewise must assess the psychological, social and even spiritual needs to provide holistic care spontaneously in totality. The approach to caring for these section of population must not be approached part by part but must consider the person as a whole. Hence, it is favored that the best approach is to aid the prisoners to deal with their physical and mental issues and provide opportunities to learn coping strategies that will assist them to have a better quality of life.

\section{REFERENCES}

Aday, R.H., Krabill, J.J. (2012). Older and geriatric offenders: critical issues for the $21^{\text {st }}$ century. In L. Gideon (ed), Special Needs Offenders in Correctional Institutions. Thousand Oaks, CA: Sage.

Anno, B.J., Graham, C., Lawrence, J.E. \& Shansky, R. (2004). Correctional Health Care: Addressing the Needs of Elderly, Chronically Ill, and Terminally Ill Inmates. Washington, DC: National Institute of Corrections, US Department of Justice; 2004. NIC Accession No. 018735.

Baidawi, S. (2016). Older prisoners: psychological distress and associations with mental health history, cognitive functioning, socio-demographic, and criminal justice factors. International Psychogeriatrics, 28(3), pp 385-395.

Baidawi, S., Turner, S., Trotter, C., Browning, C., Collier, P., O'Connor, D. \& Sheehan, R. (2011). Older prisoners A challenge for Australian corrections. Trends and Issues in Crime and Criminal Justice, 426, pp 1-8.

Bandura, A. (1977). Self-efficacy: Toward a unifying theory of behavioral change. Psychological Review, 84(2), pp 191-215. 
Bjørkløf, G.H., Engedal, K., Selbæk, G., Kouwenhoven, S.E. \& Helvik A.S. (2013). Coping and depression in old age: a literature review. Dementia and Geriatric Cognitive Disorders, 35, pp 121-154.

Crawley, E. (2005). Institutional thoughtlessness in prisons and its impact on the day-to-day prison lives of the elderly men. Journal of Contemporary Criminal Justice, 21(4), pp 350-363.

Crawley, E. \& Sparks, R. (2005). Hidden Injuries? Researching the Experiences of Older Men in English Prisons. The Howard Journal of Criminal Justice, 44(4), pp 345-356.

De Guzman, A., Santos, J.I., Santos, M.L., Santos, M.T., Sarmiento, V., Sarnillo, E. \& Sarsagat, J. (2010). Traditional Filipino Arts in Enhancing Older People's Self-Esteem in a Penal Institution. Educational Gerontology, 36(12), pp 1065-1085.

Greenberg, S. (2012). The geriatric depression scale (GDS). General assessment series. Try This: Best Practices in Nursing Care to Older Adults. The Hartford Institute for Geriatric Nursing.

Haney, C. (2002). From prison to home: The effects of incarceration and reentry on children, families, and communities. National Policy Conference: U.S. Department of Health and Human Services, The Urban Institute.

Kakoullis, A., Le Mesurier, N. \& Kingston, P. (2010). The mental health of older prisoners. International Psychogeriatrics, 22(5), pp 693-701.

Lazarus, R.S. \& Lazarus, B.N. (2006). Coping with Ageing. New York, Oxford University Press, pp 53-79.

Moos, R. (1974). Psychological Techniques in the assessment of adaptive behavior. Coelho GV, Hamburg DA, Adams JE (eds.). New York, Basic Books.

Murdoch, N., Morris, P. \& Holmes, C. (2008). Depression in elderly life sentence prisoners. International Journal of Geriatric Psychiatry, 23(9), pp 957-962.

Parse, R.R. (1997). Human Becoming: Parse's Theory of Nursing. Nursing Science Quarterly, 5(1), pp 35-42.

Patterson, E.B. (1991). Poverty, income, inequality and community crime rates. Criminology, 29(4), pp 755-776.

Poverty in The Philippines: Lack of Vision, Yet New Solutions. Retrieved From http://www.poverties.org/povertyin-the-philippines.html

Williams, B.A., Lindquist, K., Sudore, R.L. \& Walter, L.C. (2006). Being old and doing time: functional impairment and adverse experience of geriatric female prisoners. Journal of the American Geriatrics Society, 54(4), pp 702-707.

Williams, B.A., Stern, M.F., Mellow, J., Safer, M. \& Greifinger, R.B. (2012). Aging in correctional custody: setting a policy agenda for older prisoner health care. American Journal of Public Health, 102(8), pp 1475-1481.

Wolff, N. (2005). Community reintegration of prisoners with mental illness: a social investment perspective. International Journal of Law and Psychiatry, 28(1), pp 43-58. 